\title{
Seasonal effects on milk yield, erythrocytic and leukocytic indices of Kankrej cattle (Bos indicus)
}

\author{
A. Lateef ${ }^{1}$, Hemen Das ${ }^{1}$, H. H. Panchasara ${ }^{2}$, Haque Nilufar ${ }^{1}$ and M. J. Sanap ${ }^{1}$ \\ 1. Department of Physiology and Biochemistry, College of Veterinary Science and Animal Husbandry, Sardarkrushinagar \\ Dantiwada Agricultural University, Sardarkrushinagar, Dantiwada-385506, Gujarat, India; 2. Livestock Research Station, \\ Sardarkrushinagar Dantiwada Agricultural University, Sardarkrushinagar, Dantiwada-385506, Gujarat, India \\ Corresponding author: Hemen Das, email: hemenvet@rediffmail.com \\ AL: dr.alatif@live.com, HHP: harshadlrs@yahoo.co.in, HN: haquenilufar@gmail.com, MJS: sanap_vet@rediffmail.com \\ Received: 15-04-2014, Revised: 04-06-2014, Accepted:06-06-2014, Published online: 09-07-2014
}

doi: $10.14202 /$ vetworld.2014.472-477

How to cite this article: Lateef A, Das H, Panchasara HH, Nilufar H and Sanap MJ (2014) Seasonal effects on milk yield, erythrocytic and leukocytic indices of Kankrej cattle (Bos indicus), Veterinary World 7(7): 472-477.

\begin{abstract}
Aim: To assess seasonal influence on milk production and haematological indices of Kankrej cattle at different levels of productivity.

Materials and Methods: 18 lactating Kankrej cows from Livestock Research Station, Sardarkrushinagar Dantiwada Agricultural University, Sardarkrushinagar were categorized into group-I, group II and group III based on their milk yielding records. Blood samples collected from all the groups during different seasons were analyzed employing Automated Haematology Analyzer. Seasonal milk yield per animal was determined from daily milk yield records of each animal. Temperature-Humidity Index (THI) of the experimental period was calculated and correlated with milk yield of the experimental animals.

Results: Increased milk yield per animal was observed during summer despite rise in THI. Erythrocytic indices except $\mathrm{Hb}$ varied significantly with one or the other production groups within the season or amongst the seasons unlike leukocytic indices and total thrombocyte count.

Conclusion: Seasonal variations of blood indices studied may be helpful for physiological characterization of this breed and interpretation of climatic influences on productivity. Further, as milk yield was observed to be peak during summer, future study is warranted to characterize and investigate expression level of Heat shock proteins during different seasons.
\end{abstract}

Keywords: erythrocytic, Kankrej, leukocytic indices, milk yield, season, THI.

\section{Introduction}

Mammals, including ruminants, exhibit seasonal rhythms of physiological functions to cope with climatic fluctuations in order to establish equilibrium [1]. The seasonal rhythms reflect the ability of endogenous adaptive mechanism of animals to react in advance to environmental changes associated with seasons [2]. In fact, physiological equilibrium is maintained by blood and hence every change that takes place in mammalian body is reflected in the blood indices [3]. Thus, blood profile reflects physiological responsiveness of animals to its internal and external environments [4] and form the very basis for diagnosis, treatment and prognosis of many diseases [5]. Further, it is also an important tool to assess the level of stress due to various environmental stressors and nutritional factors [6]. The environmental stressors in turn vary from season to season. According to bio-climatological variables, the climate of Gujarat, India falls under semi arid zone coupled with hot and humid condition, which itself poses as harsh abiotic factor for optimum productivity of livestock. Nonetheless, Kankrej (Bos

Copyright: The authors. This article is an open access article licensed under the terms of the Creative Commons Attribution License (http://creativecommons.org/licenses/by/2.0) which permits unrestricted use, distribution and reproduction in any medium, provided the work is properly cited. indicus), a native cattle breed of the state, is known for yielding good quantity of milk with high fat content even in these extreme climatic conditions. The breed is being maintained as elite herd at Livestock Research Station (LRS), Sardarkrushinagar Dantiwada Agricultural University (SDAU), Sardarkrushinagar and proved to be superior to crossbreds and other native breeds with respect to milk production and disease resistance [7]. Surprisingly, the milk yield of this breed has been observed to be increased over the last five years during summer, though no scientific report has been made in this aspect.

It is universal that the maintenance of productivity of an animal is essentially a function of environment, since genetic potentials cannot be expressed unless a congenial environment is provided [8]. Therefore, proper understanding of how climatic factors affect the physiological response of animals provides a firm basis of improving the husbandry practices.

In the light of above discussed features, the present investigation was planned to assess the seasonal influence on milk production and haematological indices of Kankrej cattle between different production groups.

\section{Materials and Methods}

Ethical approval: The current study was carried out as a part of departmental research scheme, which was 
Table 1: Meterological data recorded at Sardarkrushinagar during different seasons

\begin{tabular}{lllcr}
\hline Season & \multicolumn{2}{c}{ Average TA $\left({ }^{\circ} \mathrm{C}\right)$} & Average RH (\%) & Rain fall (mm) \\
\cline { 2 - 3 } & Maximum & Minimum & & No. of Rainy days \\
\hline Summer & $41^{\circ} \mathrm{C}\left(106^{\circ} \mathrm{F}\right)$ & $29^{\circ} \mathrm{C}\left(84^{\circ} \mathrm{F}\right)$ & 0.0 \\
Monsoon & $35^{\circ} \mathrm{C}\left(95^{\circ} \mathrm{F}\right.$ & $27^{\circ} \mathrm{C}\left(81^{\circ} \mathrm{F}\right)$ & 75 & 589.20 \\
Winter & $29^{\circ} \mathrm{C}\left(84^{\circ} \mathrm{F}\right)$ & $12^{\circ} \mathrm{C}\left(54^{\circ} \mathrm{F}\right)$ & 50 & 0.0 \\
\hline
\end{tabular}

approved by Research Subcommittee on Animal production, Sardarkrushinagar.

Place of study: The study was conducted at College of Veterinary Science and A.H, Sardarkrushinagar in Banaskantha district of North Gujarat, India. It lies between latitude $24.5^{\circ} \mathrm{N}$ and longitude $72^{\circ} \mathrm{E}$ and at an elevation of 189 meters above the mean sea level. The climate of the region is very harsh for livestock entrepreneurship.

Experimental animals: For the study, 18 lactating Kankrej cows ( $>4$ parities) from the elite herd reared at LRS, SDAU, Sardarkrushinagar were selected and categorized into three groups of six animals each viz. group-I (low yielder, $<2,5001 /$ per lactation), group II (medium yielder, 2,500-3,500 1/per lactation) and group III (high yielder, $>3,500$ 1/per lactation) based on consistent milk yield records in their earlier lactations. All the animals were clinically healthy with no physical deformities. Standard feeding and managemental practices were followed during the study period. The animals were housed in a well ventilated shed having concrete pucca floor and fed concentrate mixture according to milk yield as well as ad libitum mixed seasonal green fodders. The animals were also examined to be free of endoparasites as anthelmintics are regularly fed to the animals reared at the research station. The health status of the selected animals was regularly evaluated based on behavior, rectal temperature, pulse rate and respiratory rate during the experimental period.

Meterological observations: The meterological data of Sardarkrushinagar viz. ambient temperature (TA), relative humidity $(\mathrm{RH})$, total rainy days and rain fall corresponding to the experimental period (March, 2012 to February, 2013) were obtained from the Department of Meterology, Chimanbhai Patel College of Agriculture (CPCA), SDAU, Sardarkrushinagar. The experimental period was divided into three phases coinciding with the three major seasons of the year i.e. summer (March to June), monsoon (July to October) and winter (November to February).

Temperature humidity index (THI): THI of Sardarkrushinagar for the experimental year was calculated based on the meterological data employing the following equation [9].

$\mathrm{THI}=0.72(\mathrm{~W}+\mathrm{D})+40.6$

Where, W: wet bulb temperature $\left({ }^{\circ} \mathrm{C}\right)$

D: dry bulb temperature $\left({ }^{\circ} \mathrm{C}\right)$

Seasonal milk yield: Seasonal milk yield per animal was determined from the daily milk yield of each animal recorded at LRS, SDAU, Sardarkrushinagar.

Collection of blood samples: $10 \mathrm{ml}$ of blood sample was collected aseptically from each animal of experimental groups by jugular vein puncture into collection tubes containing anticoagulant, $\mathrm{K}_{3}$ EDTA.

Haematological analysis: Blood samples were analyzed for different hematological parameters viz. total erythrocyte count (TEC), haematocrit (HCT)/ packed cell volume (PCV), haemeoglobin $(\mathrm{Hb})$, mean corpuscular volume (MCV), mean corpuscular hemoglobin $(\mathrm{MCH})$, mean corpuscular hemoglobin concentration (MCHC), total leucocyte count (TLC), differential leucocyte count (DLC) and platelet/thrombocyte count (PLTs) using Automated Haematology Analyzer (Cell-Dyn 3700, Abbott Diagnostics, USA).

Statistical analysis: The results were statistically analyzed using two-way ANOVA as per method of Snedecor and Cochran [10]. $p<0.05$ were considered to be statistically significant.

\section{Results}

Meterological data: Data of different meterological variables have been presented in Table-1. The highest ambient temperature was recorded in May, 2012 during summer, while it was lowest in January, 2013 during winter. The relative humidity was minimum during summer and maximum during monsoon. Total rainfall recorded during the experimental period was only of monsoon season as there was no rainy day during summer and winter.

THI: Figure-1 reveals that THI was $>80$ during 10-22 weeks i.e. mid May to July, 2012 and was between 5966 during 49-52 weeks of the experimental year i.e. February, 2013. Nonetheless, the THI was calculated to be highest at 19 weeks; whereas, it was lowest at 49 weeks of the year.

Seasonal milk yield: Total milk yield (litre) per animal recorded during the three seasons has been presented in Figure-2. It was recorded to be peak during summer, while it dipped down during winter season.

Erythrocytic indices and thrombocyte count: Table-2 indicates the seasonal variation in mean values of erythrocytic indices and thrombocyte counts of different experimental groups. Except haemoglobin, all erythrocytic indices showed significant variation with one or the other production groups within the season or amongst the seasons. R.B.C count was significantly lower in high yielding group during monsoon; whereas, it was the highest during summer. 


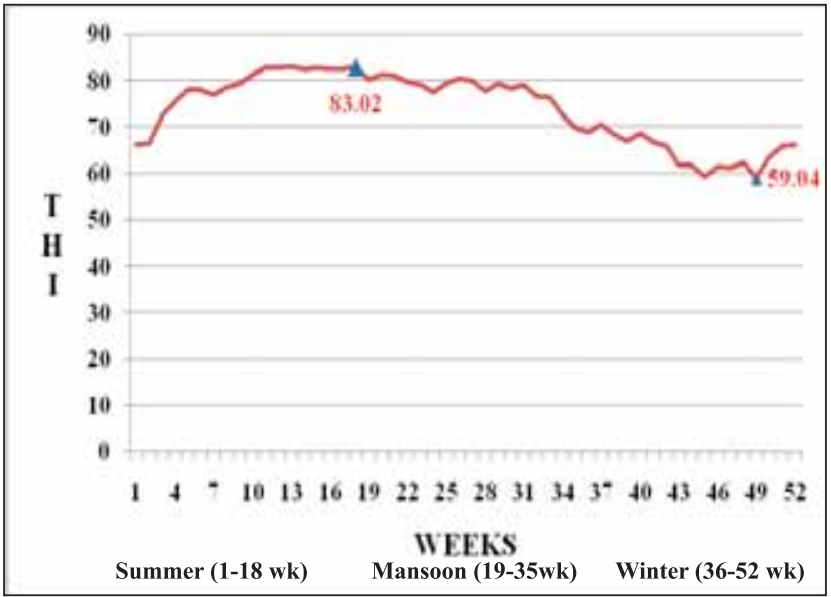

Figure-1: THI of Sardarkrushinagar during the experimental period.

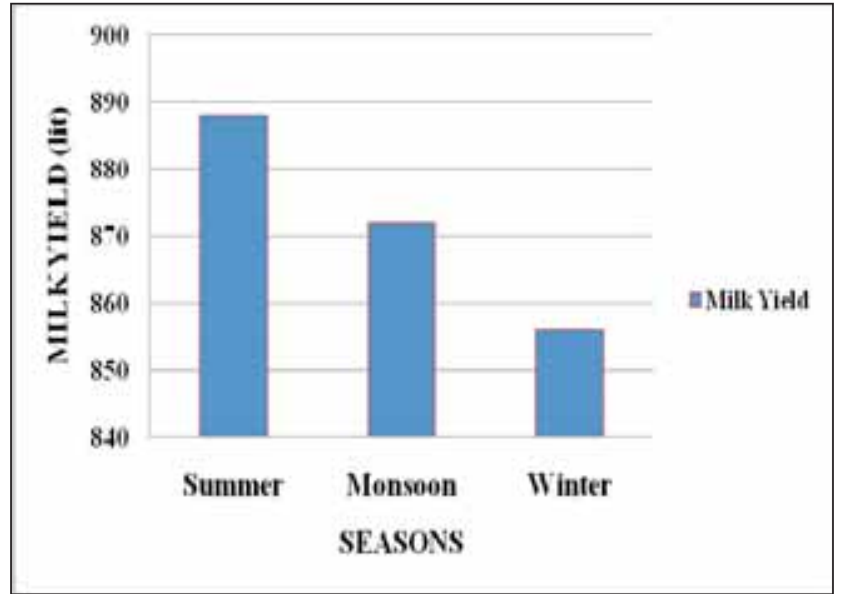

Figure-2: Seasonal variation of milk yield litre/animal.

Table-2: Mean values of erythrocytic indices and thrombocyte count of different experimental groups

\begin{tabular}{|c|c|c|c|c|c|c|c|}
\hline Season & TEC/RBCs (M/NI) & HGB (g/dl) & НCT (\%) & $\operatorname{MCV}(\mathrm{fl})$ & MCH (pg) & MCHC (g/dl) & 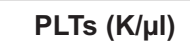 \\
\hline \multicolumn{8}{|l|}{ Winter } \\
\hline High yielder & $6.55 \pm 0.29^{a b}$ & $10.62 \pm 0.47^{a}$ & $28.06 \pm 1.04^{a}$ & $44.56 \pm 0.90^{\mathrm{a}}$ & $15.53 \pm 0.49^{a}$ & $35.29 \pm 0.64^{a}$ & $403.90 \pm 29.70^{\circ}$ \\
\hline Low yielder & $6.15 \pm 0.28^{\mathrm{a}}$ & $11.53 \pm 0.73^{\mathrm{a}}$ & $25.33 \pm 8.10^{a}$ & $38.85 \pm 12.28^{b}$ & $19.55 \pm 6.18^{b}$ & $48.59 \pm 3.73^{b}$ & $399.50 \pm 39.63^{c}$ \\
\hline $\begin{array}{l}\text { Medium yielder } \\
\text { Summer }\end{array}$ & $7.46 \pm 0.36^{b}$ & $11.80 \pm 0.43^{\mathrm{a}}$ & $32.24 \pm 11.78^{\mathrm{a}}$ & $42.00 \pm 13.28^{a}$ & $16.18 \pm 5.12^{\mathrm{a}}$ & $36.98 \pm 0.75^{a}$ & $576.92 \pm 13.64^{\circ}$ \\
\hline High yielder & $8.34 \pm 0.43^{a}$ & $12.41 \pm 0.55^{a}$ & $34.94 \pm 1.09^{a}$ & $44.56 \pm 0.90^{\mathrm{a}}$ & $15.53 \pm 0.49^{\mathrm{a}}$ & $35.29 \pm .64^{\mathrm{a}}$ & $403.90 \pm 29.70^{\circ}$ \\
\hline Low yielder & $6.81 \pm 0.38^{b}$ & $12.47 \pm 0.52^{\mathrm{a}}$ & $32.13 \pm 8.26^{a}$ & $38.91 \pm 12.30^{b}$ & $19.65 \pm 6.21^{b}$ & $48.60 \pm 3.73^{b}$ & $390.80 \pm 41.38^{\circ}$ \\
\hline $\begin{array}{l}\text { Medium yielder } \\
\text { Monsoon }\end{array}$ & $7.10 \pm 0.58^{a}$ & $12.76 \pm 0.66^{\mathrm{a}}$ & $36.94 \pm 11.68^{\mathrm{a}}$ & $42.00 \pm 13.28^{a}$ & $16.18 \pm 5.12^{\mathrm{a}}$ & $36.98 \pm 0.75^{\mathrm{a}}$ & $570.92 \pm 23.64^{\circ}$ \\
\hline High yielder & $5.80 \pm 0.58^{\mathrm{a}}$ & $15.87 \pm 3.12^{a}$ & $39.53 \pm 1.02^{a}$ & $47.35 \pm 1.71^{\mathrm{a}}$ & $15.85 \pm 0.55^{a}$ & $34.11 \pm 0.48^{a}$ & $417.80 \pm 98.27^{\circ}$ \\
\hline Low yielder & $6.71 \pm 0.30^{\mathrm{a}}$ & $16.46 \pm 3.31^{a}$ & $40.53 \pm 9.65^{a}$ & $45.60 \pm 14.42^{\mathrm{a}}$ & $15.88 \pm 5.02^{a}$ & $34.82 \pm 0.49^{a}$ & $515.10 \pm 76.20^{\circ}$ \\
\hline Medium yielder & $7.12 \pm 0.31^{a}$ & $15.74 \pm 2.36^{\mathrm{a}}$ & $41.93 \pm 9.78^{a}$ & $44.08 \pm 13.94^{a}$ & $15.72 \pm 4.97^{\mathrm{a}}$ & $35.68 \pm 0.70^{a}$ & $483.00 \pm 33.26^{\circ}$ \\
\hline
\end{tabular}

Mean \pm S. E. bearing similar superscript within the columns are non-significant at $0.05 \%$ level of probability

Table-3: Mean values of leukocytic indices of different production groups

\begin{tabular}{lcccccc}
\hline Season & WBCs/TLC (K/Ml) & Neutrophils (\%) & Lymphocytes (\%) & Monocytes (\%) & Eosinophils (\%) & Basophils (\%) \\
\hline Winter & & & & & & \\
High yielder & $10.52 \pm 0.53^{\mathrm{a}}$ & $28.42 \pm 0.23^{\mathrm{a}}$ & $64.43 \pm 0.68^{\mathrm{a}}$ & $4.12 \pm 0.31^{\mathrm{a}}$ & $2.54 \pm 1.02^{\mathrm{a}}$ & $0.01 \pm 0.02^{\mathrm{a}}$ \\
Low yielder & $8.12 \pm 0.83^{\mathrm{a}}$ & $32.42 \pm 0.29^{\mathrm{a}}$ & $65.43 \pm 0.62^{\mathrm{a}}$ & $4.52 \pm 0.29^{\mathrm{a}}$ & $2.61 \pm 0.99^{\mathrm{a}}$ & $0.01 \pm 0.02^{\mathrm{a}}$ \\
Medium yielder & $8.85 \pm 0.83^{\mathrm{a}}$ & $31.56 \pm 0.41^{\mathrm{a}}$ & $66.29 \pm 57^{\mathrm{a}}$ & $4.43 \pm 0.30^{\mathrm{a}}$ & $2.59 \pm 1.10^{\mathrm{a}}$ & $0.01 \pm 0.03^{\mathrm{a}}$ \\
Summer & & & & & \\
High yielder & $9.59 \pm 0.38^{\mathrm{a}}$ & $26.32 \pm 0.13^{\mathrm{a}}$ & $65.21 \pm 0.71^{\mathrm{a}}$ & $6.20 \pm 0.28^{\mathrm{b}}$ & $3.21 \pm 1.11^{\mathrm{a}}$ & $0.01 \pm 0.03^{\mathrm{a}}$ \\
Low yielder & $7.25 \pm 0.64^{\mathrm{a}}$ & $29.41 \pm 0.31^{\mathrm{a}}$ & $62.43 \pm 0.65^{\mathrm{a}}$ & $4.25 \pm 0.34^{\mathrm{a}}$ & $3.10 \pm 1.14^{\mathrm{a}}$ & $0.01 \pm 0.02^{\mathrm{a}}$ \\
Medium yielder & $8.83 \pm 0.57^{\mathrm{a}}$ & $27.55 \pm 0.27^{\mathrm{a}}$ & $64.18 \pm 66^{\mathrm{a}}$ & $4.01 \pm 0.30^{\mathrm{a}}$ & $3.14 \pm 1.18^{\mathrm{a}}$ & $0.01 \pm 0.02^{\mathrm{a}}$ \\
Monsoon & & & & & \\
High yielder & $9.62 \pm 0.44^{\mathrm{a}}$ & $29.51 \pm 0.39^{\mathrm{a}}$ & $63.34 \pm 0.59^{\mathrm{a}}$ & $4.64 \pm 0.26^{\mathrm{a}}$ & $2.89 \pm 0.89^{\mathrm{a}}$ & $0.00 \pm 0.00$ \\
Low yielder & $8.04 \pm 0.52^{\mathrm{a}}$ & $32.32 \pm 0.22^{\mathrm{a}}$ & $61 \pm 0.74^{\mathrm{a}}$ & $4.59 \pm 0.27^{\mathrm{a}}$ & $2.92 \pm 0.96^{\mathrm{a}}$ & $0.01 \pm 0.02^{\mathrm{a}}$ \\
Medium yielder & $9.68 \pm 0.63^{\mathrm{a}}$ & $30.32 \pm 0.26^{\mathrm{a}}$ & $65.52 \pm 62^{\mathrm{a}}$ & $4.52 \pm 0.31^{\mathrm{a}}$ & $2.87 \pm 0.90^{\mathrm{a}}$ & $0.01 \pm 0.02^{\mathrm{a}}$ \\
\hline
\end{tabular}

Mean \pm S. E. bearing similar superscript within the columns are non-significant at $0.05 \%$ level of probability

$\mathrm{MCV}$ and $\mathrm{MCH}$ varied significantly amongst the three groups during winter and summer seasons. However, the variation observed for these two parameters amongst the different groups during monsoon season was nonsignificant. Nonetheless, there was an increasing trend of HCT value from winter to monsoon season. Further, it was observed that the platelet counts were not significantly influenced by season and thus remains comparable in all the three seasons of the year.
Leukocytic indices: Table-3 shows the seasonal alteration in mean values of the leukocytic indices. It was observed that TLC was not significantly affected by milk yield and seasons. Table-3 further reveals that the influence of season on the ratios of neutrophils, lymphocyte, eosinophils and basophils was not significant. However, the monocyte count of the high yielding group in summer season was significantly higher as compared to other production groups and seasons. 


\section{Discussion}

Gujarat is geographically endowed with diverse climatic conditions throughout the year. During the experimental period, the animals got exposed to marked seasonal changes in ambient temperature and humidity as evidenced by Table- 1 . The variation in climatic variables like temperature, humidity and radiation are recognized as the potential hazards for the growth and production of all domestic livestock species [11]. Among the climatic stressors, summer stress has been the major factor contributing to low milk yield and low fertility of lactating animals, (especially in animals of high genetic merit) in tropical, sub-tropical and arid regions [12]. Usually, rectal temperature and respiration rate are considered as indices of degree of climatic stress to which the animals are exposed. However, THI has been conventionally used as sensitive indicator of climatic stress on animals and is interpreted that THI values of 70 or less as comfortable, 75-78 as stressful, and values $>78$ cause extreme distress in lactating animals making them unable to maintain thermoregulatory mechanisms or normal body temperatures leading to lower milk yield [13].

Contrary to the previous reports and perception, current findings indicate that seasonal milk yield per animal of elite Kankrej herd maintained at LRS, SDAU, Sardarkrushinagar increased during summer as compared to winter and monsoon seasons. Further, correlating milk yield with calculated THI, it was observed that with continuous increase in the THI, the milk yield per animal increased during summer. This typical characteristic of Kankrej cattle may be attributed to the adaptability of this breed to the geoclimatic conditions of North Gujarat. In fact, Kankrej, one of the prolific indigenous breed of cattle, has evolved over the centuries through natural selection for adaptation to harsh climatic conditions and resistant to common tropical diseases. They can also survive on poor quality residual grass with scanty drinking water, and well known for its milk yielding ability [14]. It may further be substantiated with the report that these indigenous breeds of cattle have adapted to the prevailing environmental condition of the native tract acquiring specific gene combination [15]. Hence, considering the unique production trait typical of Kankrej cattle, genetic characterization of this breed becomes imperative to identify the gene, if any, encoding stress modulating protein such as heat shock protein (HSP), so that such a protein may be up regulated and/or expressed in desirable breed/species of milch animals through genetic engineering for the purpose of selecting the animals through genetic improvement program. This may probably be one of the mitigation strategies to cope up with climate change consequent upon global warming ensuring the viability of dairy industry.

Nevertheless, current study reflects that seasonal fluctuations alter the physiological responses of animals including blood indices. Table- 2 indicates that $\mathrm{Hb}$ concentrations recorded in all the experimental groups were within the physiological limit and showed no significant variation amongst the experimental groups. Previous studies also demonstrated no significant seasonal effect on $\mathrm{Hb}$ concentration [16]. However, it was apparently higher during summer and monsoon than that of winter. This finding partially coincides with that of Naik et al. [17], who also observed higher $\mathrm{Hb}$ level in summer. The higher $\mathrm{Hb}$ concentration during summer and monsoon may be because of increased total $\mathrm{Fe}^{+}$concentration during the two seasons [18] or could be due to hemo-concentration observed in stressful condition of hot and high humidity during summer and monsoon, respectively [19]. The mean TEC varied amongst different seasons with the highest value recorded during summer and lowest value during monsoon in the high yielding group. These findings are in accordance with those of Babeker et al. [16], who had also noticed similar trend of variation in dromedary camels. However, these observations appeared to be contradictory to the findings of Soley and Singh [20] in dairy cattle and Mirzadeh et al. [21] in Iranian cattle as reduced TEC were found during summer season. Whereas, other study [22] indicated that season had no effect on TEC in Holstein Swiss brown and their cross breeds. Conversely, Prava and Dixit [23] observed higher TEC during summer in calves and lactating cow $\geq 5$ years of age. The summer increase of TEC might be due to adaptive mechanism of the breed to improve oxygen carrying capacity of blood during hot environment [17]. In the present study, the HCT value did not differ significantly among the production groups as well as during different seasons. This is in agreement with the findings of Naik et al. [17] in case of Punganur cattle. The apparent increase in HCT during summer and monsoon may be ascribed to the high temperature and humidity, respectively. It is reported that hot and humid environment stimulates sweating causing loss of water leading to hemo-concentration and a hike in TEC and thereby HCT value [24]. Table-2 further reveals that $\mathrm{MCV}$ was significantly lower, but MCH and MCHC were significantly higher in low yielding group during winter and summer seasons. The low value of MCV could be related to the negative correlation between size and number of erythrocytes. Nonetheless, the relative fluctuation of $\mathrm{MCV}, \mathrm{MCH}$ and $\mathrm{MCHC}$ observed in the present study may be attributed to concomitant increase or decrease in $\mathrm{Hb}$ concentration or HCT [9].

Table-3 indicates that the TLC showed apparently limited fluctuation ranging between $7.00 \times 10^{3} / \mu 1$ and $10.50 \times 10^{3} / \mu 1$. There were no marked seasonal changes in TLC amongst the experimental groups. Similar findings were also previously reported in goats by Abdelatif et al. [9]. However, the highest values of TLC were recorded during winter with a slight reduction during the other two seasons. This reduction 
may be associated with physiological responses to hot and humid climate. Contrary to the current observations, previous study [25] recorded significantly lower level of TLC in local cattle during winter as compared to summer season and concluded that the summer increase of TLC might be due to higher levels of parasitic infection observed during hot humid conditions of summer.

The present study further revealed that the seasonal change in climate had no significant effects on the ratios of neutrophils, lymphocytes, eosinophils and basophils. However, the ratio of neutrophil and lymphocyte $(\mathrm{N}: \mathrm{L})$ was apparently higher during summer. In fact, the $\mathrm{N}$ : $\mathrm{L}$ is the most common index of measurement of stress and adaptability of the animals to the local environment, which generally increases under stress condition [26]. Similarly, the monocyte count was found to be higher in summer as compared to winter and monsoon. This finding is consistent with earlier report in case of goats [27]. The increase monocyte count recorded during summer could be associated with increased cortisol secretion. Monocytes respond to elevation of blood corticosteroid concentration, but species differences are seen with the type of response and the mechanism of monocytosis [28].

\section{Conclusion}

Present study, thus, will assist in proper understanding of how climatic factors affect the physiological responses of Kankrej cattle in terms of haematological indices and milk yield. Further, data generated during the study may be helpful for physiological characterization of this breed and helps in interpretation of climatic influences on productivity. However, a future research is warranted to investigate the expression and/or upregulation of HSPs and to study their role in summer increase of milk yield typical of this unique breed of Gujarat.

\section{Authors' contributions}

$\mathrm{AL}$ and HD designed and carried out the experiment. HHP collected the blood sample. HD and HN prepared the manuscript. HN and MJS drafted the manuscript. $\mathrm{AL}$ and $\mathrm{HD}$ revised the final draft of the manuscript. All authors read and approved the final manuscript.

\section{Acknowledgements}

The authors are grateful to Research Scientist, Livestock Research Station and Dean, College of Veterinary Science and A.H., SDAU, Sardarkrushinagar for providing necessary support and funds to carry out the research work. Thanks are also due to the Head, Department of Meterolology, CPCA, SDAU for providing the meterological data of the experimental period.

\section{Competing interests}

The authors declare that they have no competing interests.

\section{References}

1. Duarte, G., Nava-Hernandez, M.P., Malpaux, B. and
Delgadillo, J.A. (2010) Ovulatory activity of female goats adapted to the subtropics is responsive to photoperiod. Anim. Reprod. Sci., 120:65-70.

2. Piccione, G., C. Giannetto, S. Casella, G.Caola (2009) Annual rhythms of some physiological parameters in Ovis aries and Capra hircus. Biol. Rhythm Res., 40:455-464.

3. Casella, S., Sciano, S., Zumbo, A., Monteverde, V., Azio, F. and Piccione,G. (2012) Effect of seasonal variations in Mediterranean area on haematological profile in dairy cow. Comp. Clin. Pathol., 22(4):691-695.

4. Esonu, B.O., Emenalom, O.O., Udedebie, U., Herbert, D. F., Ekpori, I.C. and Iheukwuemere, F.C. (2001) Performance and blood chemistry of weaned pigs fed raw mucuna bean (velvet bean) meal. Trop. Anim. Prod. Invest. 4:49-54.

5. De, A.K., Kundu, A., Kundu, M.S., Sunder, J and Jeyakumar, S.(2013) Comparative study on haematological traits of endangered Andaman wild pig and other indigenous pig breeds available at Andaman and Nicobar Islands, India Vet. World, 6:794-798.

6. Mmereole, F.U.C. (2008) The effects of replacing groundnut cake with rubber seed meal on haematological and serological indices of broilers. Int. J. Poult. Sci. 7(6):622624.

7. Patel, B.R. and Siddiquee, G.M. (2013) Physical and morphological characteristics of Kankrej bull semen. Vet. World. 6(7): 405-408.

8. Abdelatif, A.M., Ibrahim, M.Y. and Hassan, Y.Y. (2009) Seasonal variation in erythrocytic and leukocytic indices and serum proteins of female Nubian goats. Middle-East J. Sci. Res., 4(3):168-174.

9. NRC. (1971) A Guide to Environmental Research on Animals. Natl. Acad. Sci., Washington, DC.

10. Snedecor, G. W. and Cochran, W. G. (1994) Statistical Method. $8^{\text {th }}$ Edn. Oxford and IBH Publishing Co., New Delhi. p156-159.

11. West, J.W. (2003) Effect of heat stress on production in dairy cattle. J. Dairy. Sci., 86(6):2131-2144.

12. Ganaie, A.H., Ghasura, R.S., Mir, N.A., Bumla, N.A., Sankar, G. and Wani, S.A. (2013) Biochemical and Physiological Changes during Thermal Stress in Bovines: A Review. Iranian J. App. Anim. Sci., 3 (3): 423-430.

13. Kadzere C.T., Murphy M.R., Silanikove N. and Maltz, E. (2002) Heat stress in lactating dairy cows: a review. Livest. Prod. Sci., 77: 59-91.

14. Upreti, M., Faridi, F.N., Maherchandani, S., Shringi, B.N. and Kashyap, S. K. (2012) Genetic diversity study of indigenous cattle (Gir and Kankrej) population of Rajasthan using microsatellite markers. African J. Biotech., 11(97): 16313-16319.

15. Deepika and Salar, R.K. (2012) Genetic Diversity and Bottleneck Analysis of Indigenous Grey Cattle Breeds of India Based on Microsatellite Data. DHR-IJBLS., 3(1): 174-184.

16. Babeker, E.A., Elmansoury, Y.H.A. and Suleem, A.E. (2013) The influence of seasons on blood constituents of Dromedary camel (Camelus dromedarius). Online J. Anim. Feed Res., 3(1): 1-8.

17. Naik, B.R., Siva Kumar, A.V.N., Ravi, A., Bramhaiah, K.V. and Praveen, V. (2013) Effect of seasons on physiological and hematological values in Punganur cattle. Int. J. Pharm. Bio. Sci., 4(4): (B) 40-49.

18. Shrikhande, G.B., Rode, A.M., Pradhan, M.S. and Satpute, A.K. (2008) Seasonal effect on the composition of blood in cattle. Seasonal effect on the composition of blood in cattle. Vet. World, 1(11):341-342.

19. Gadariya, M.R., Patel A and Dhamia.A J. (2008) Influence of work stress on certain blood constituents of bullocks subjected to cart loads and ploughing under comfort and stressful climatic conditions. Indian J. Dairy Sci., 61: 66-69.

20. Soley, M. J. and Singh S. V. (2003) Physiological, haematological and growth responses of crossbred male calves under two housing conditions. Indian J. Anim. Sci., 
73(2): 202-203.

21. Mirzadeh, K. H. Tabatabaci S, Bojarpur M and Mamoei M.(2010) Comparative study of haemological parameters according strain, age, sex, physiological status and season in Iranian cattle. J. Anim. Vet. Adv., 9(16): 2123-2127.

22. Ozdemir, H, Sezer K and Kilic S. (2005) Seasonal levels of same Haematological Parameters in Dairy Cows. Indian Vet.J. 82: 756-758.

23. Prava, M. and Dixit N K. (2008) Effect of season on Blood erythrocyte picture of Frieswal cattle. Indian J. Dairy Sci. 61(2): 162-164.

24. Piccione, G., Casella, S., Lutri, L. and Vazzana, I. (2010) Reference values for some haematological, haematochemical, and electrophoretic parameters in the Girgentana goat Turk. J. Vet. Anim. Sci., 34(2): 197-204.

25. Al-Saeed, M.H., Hardik, K.A. and Ghadhabam, R.F. (2009) Selective evaluation of certain blood and biochemical parameters of local cattle during winter and summer seasons. Bas. J. Vet. Res., (8):1:138-143.

26. Minka, N.S. and Ayo, J.O. (2007) Physiological responses of transported goats treated with ascorbic acid during the hot dry season. Anim. Sci. J., 78(2):164-172.

27. Al-Busaidi, R., Johnson, E.H. and Mahgoub, O. (2008) Seasonal variations of phagocytic response, immunoglobulin $\mathrm{G}(\mathrm{IgG})$ and plasma cortisol levels in Dhofari goats. Small Ruminant Res., 79:118-123.

28. Jain, N.C. (1993) Essentials of Veterinary Haematology. 1st edition. Philadelphia, USA: Lea \& Febiger; p295-306.

$* * * * * * * *$ 